\title{
Functional Foods for Obesity Management
}

\author{
Rajitha Sunkara, Martha Verghese* \\ Nutritional Biochemistry Laboratory, Food and Animal Sciences, Alabama A\&M University, Normal, USA \\ Email: rajitha.sunkara@aamu.edu, martha.verghese@aamu.edu
}

Received 23 May 2014; revised 27 June 2014; accepted 11 July 2014

Copyright (C) 2014 by authors and Scientific Research Publishing Inc.

This work is licensed under the Creative Commons Attribution International License (CC BY).

http://creativecommons.org/licenses/by/4.0/

c) (i) Open Access

\begin{abstract}
Obesity is a global problem and numbers are rising at a fast pace in developing countries and it becomes a major public health concern. Economic costs associated with obesity are high and increasing as the rate of obesity. Obesity leads to its co-morbidities; namely diabetes, hypertension, cardiovascular diseases, osteoarthritis, stroke and inflammatory diseases. Changes in life-style along with modifications to the diet are important in the management of obesity. Certain dietary components and foods have the ability to induce thermogenesis and modify the trafficking of nutrients in the body. Positive effects in managing obesity by natural components, and selected foods have drawn attention due to the potential side effects of obesity drugs. The food industry has developed low-density foods to reduce energy intake. Now focus has been geared towards the development of foods that possess more than one mechanism to alter the progression of obesity. In this review, selected foods and their components with potential anti-obesity properties are discussed.
\end{abstract}

\section{Keywords}

\section{Obesity, Functional Foods, Satiety, Energy Expenditure}

\section{Introduction}

Obesity is a condition, which results from the lack of energy balance in the body or by positive energy balance. Despite various programs implemented to reduce obesity rate, it continues to be the major public health concern. In United States, one third of the adult population is obese and $17 \%$ of children suffer from obesity [1]. Over the past decade, obesity in infants and preschool children has been reduced from $13.8 \%$ to $8.1 \%$. However, the rate of obesity remains constant in other age groups. Developing countries suffer from both over-nutrition and under-nutrition. The increase in number of over-weight individuals has tripled in last 30 years among the developing countries and reached more than 900 million by 2008. Whereas, rise in the rate of overweight in developed countries was 1.7 times during the same period [2]. The alarming rate of increase in overweight or obesity in developing countries and steady growth in developed countries needs attention.

\footnotetext{
*Corresponding author.
} 
Changes in the life style and behavior patterns have been contributed to the prevalence of obesity. Availability of energy-dense foods at low cost, decreased physical activity, urbanization, and an increased sedentary life style are some of the factors that might influence the rise of overweight and obesity. Obesity is a serious threat to public health and results in a huge hike in health care costs. Cost for treating obese individuals in US has increased 10\% annually, equaling about $\$ 147$ billion in the year 2008 [3].

Very few drugs are available in the market to treat obesity, however they are prescribed to treat mainly advanced stage of obesity [4] [5]. Many of the approved drugs used to treat obesity were withdrawn from the market due to their potential hazardous effects over the long-term consumption. Behavioral interventions including diet modification and increased physical activity have long been introduced. However, the effectiveness and practice of a strict regimen has been a problem [6] [7]. Therefore, focus has been given for alternative strategies to fill the need of safe anti-obesity agents. Researchers in the past decade have focused on evaluating efficacy of dietary and natural bioactive components that may modulate the pathophysiology of obesity. Food industry has tremendous opportunities to develop functional foods to meet the demands of health-conscious consumers due to an increased awareness for prevention of diseases by adoption of a healthy eating pattern.

Functional foods are defined in various ways by several agencies and authorities [8]. According to The IFT Expert Panel Report, Functional Foods Opportunities and Challenges, "functional foods" are defined as foods and food components that provide a health benefit beyond basic nutrition (for the intended population) [9]. These substances provide essential nutrients often beyond quantities necessary for normal maintenance, growth, and development, and/or other biologically active components that impart health benefits or desirable physiological effects.

Obesity is a multifactorial condition developing from an interface of genetic, environmental, behavioral, life style, cultural and metabolic factors. It may lead to development of the comorbidities such as cancer, hypertension, diabetes, dyslipidemia, atherosclerosis and others. Obesity results from an imbalance of energy expenditure and energy intake. Development of foods/components in the prevention of obesity should target either one or both these factors. Functional foods for obesity management should have the ability to induce satiety, reduce appetite, modulate lipid metabolism, affect adipocyte life cycle and induce thermogenesis. After a year of systemic diet therapy, women and men significantly modified their eating pattern by increasing the intake of dark bread, rice, vegetables, cottage cheese, fish compared to pasta, potatoes, ripened cheese, sugar, meat, bacon, lard, butter and cream. Weight gain was reduced by $1.2 \mathrm{~kg}$ in men and $2.4 \mathrm{~kg}$ in women. Analyzed biochemical markers (LDL and triglyceride levels) were reduced. However, the rise in HDL and significant change in systolic blood pressure were seen only in women [10].

Reduction in energy intake may be obtained by increasing satiety with low-density satisfying foods, and rheological modification of foods and by reduced energy absorption in the gut. Satiety and appetite regulation is a complex interaction of neural and hormonal interactions. Food components that modulate intestinal or peripheral satiety peptides, hypothalamic neuropeptides and central nervous system (CNS) appetite transmitters are the agents for weight regulation via reducing food intake [11]. Fiber induces satiety by increasing gastric load, and emptying time, which may increase cholecystokinin and reduce ghrelin [12]. Intestinal lipase inhibitors obstruct fat digestion and absorption, and thereby possess applications in the management of obesity. Phenols, tannins and anthocyanins present in tea, berries, and peas exhibited in-vitro lipase inhibition activity [13] [14]. Among the coffee polyphenols, di-caffeoyl quinic acids (di-CQA) showed more potent inhibitory activity on digestive enzymes (maltase, sucrose and lipase), thereby playing a role in post-prandial hyperglycemia and hyperinsulinaemia [15].

Increased energy expenditure has an effect in reducing body weight gain. Brown adipocyte tissue posses an innate mechanism for regulated heat production of excess energy by uncoupled proteins (UCP) at mitochnondria. Capaisin, caffeine, green tea induce thermogenesis and are being used as anti-obesity agents [16]. Regulating lipid metabolism by increasing lipolysis is another mechanism of natural anti-obesity agents. Obesity is also characterized by an increase in number and size of adipocytes which are differentiated for preadipocytes. Food components that regulate adipocyte differentiation induce cell cycle arrest, and apoptosis are likely candidates to use for obesity management [16]. Obesity is associated with chronic low-grade inflammation, which is evident by high production of inflammatory cytokines. Targeting inflammatory regulators such as nuclear factor- $\kappa \mathrm{B}$ and C-Jun amino-terminal kinase (JNK) using food components may be a strategy to control obesity-related pathologies [17]. 


\section{Carbohydrate Based Food}

$\gamma$-oryzanol is a mixture of ferulic acid esters and present in bran of brown rice. The effect of brown rice and $\gamma$-oryzanol on preference of dietary fat in mice was studied by Kozuka et al. (2012). The study revealed that mice fed with either brown rice or $\gamma$-oryzanol, preferred a control diet with normal fat over high fat diet. The preference for low dietary fat might been through the reduction of hypothalamic endoplasmic reticulum (ER) stress [18].

Dietary fiber plays a role in prevention of risks of chronic diseases via various mechanisms. The glycemic index (GI) of carbohydrates and content of fiber in foods affects the weight gain. Animal studies have shown that consuming diets with high GI starches lead to weight gain, high visceral adiposity and lipogenesis compared to diets based on low GI starches [19] [20]. Fermentation of soluble fiber produces short chain fatty acids by the action of intestinal bacteria. Butyric acid is one of short chain fatty acids and is metabolically important among others in modulating obesity. Butyric acid supplementation reduced body fat by $10 \%$ in mice along with an increase in fat oxidation, hepatic energy expenditure, and PPAR $\gamma$ mediated PPAR $\alpha$ expression [21]. Butyric acid also modulated substrate trafficking in hepatic tissue by increasing fat oxidation and glycogen storage [22].

Macronutrient composition of the diet is important in inducing satiety and reducing appetite. A moderate increase in protein content along with a reduced high GI foods and moderate fat prevented regain of weight in obese patients [23].

\section{Protein Based Foods and Components}

Legumes rich in protein also contain phenolic compounds such as flavonoids, isoflavones, phenolic acids and lignans. They play a critical role in metabolism [24]. Evidence has shown that diets rich in protein induces satiety, suppresses appetite and food intake [25]. Protein in general induces high satiety and thermeogenic effects compared to its macronutrient counterparts carbohydrates and fats because of high demand of energy associated with catabolism, and protein synthesis [26].

Supplementation of legumes at 4 servings/week with a hypocaloric diet to obese individuals for 8 weeks in an intervention study reduced body weight, cholesterol level, oxidized low density lipoprotein (LDL) levels and improved plasma antioxidant levels [27]. Incorporating legumes in weight loss programs have offered satiety and improved the effects of calorie restriction on lean body mass and basal metabolic rate [28].

Plant protein bromelain inhibited adipocyte differentiation in 3T3L1 adipocyte cells by inducing apoptosis and lipolysis and by decreasing adipogenic gene expression. Adipogenesis was reduced via downregulating $\mathrm{C} / \mathrm{EBP} \alpha$ and $\mathrm{PPAR} \gamma$ independent of $\mathrm{C} / \mathrm{EBP} \beta$ gene expression. Bromelein reduced adiponectin expression and secretion [29].

Peas, lentils and Faba beans are rich in glutamine, and they increased energy expenditure by $49 \%$ in human subjects [30]. Supplementing chickpeas with a high fat diet in rats promoted energy expenditure with similar energy input [31]. Effect of black soy peptides in reducing body weight and fat were tested in humans for 12 week period. After 12 weeks, there was a significant reduction in body fat, weight gain and leptin levels [32].

In a study, the effect of soy protein isolate added to a calorie restricted diet was evaluated for weight gain, fat content, adiponectin levels and gene expression of fatty acid and glucose metabolism in mice. Body weight gain, and fat content were significantly reduced in soy protein isolate fed mice compared to the casein fed mice. However, the level and expression of adiponectin were not affected by feeding soy protein isolate [33]. In a randomized control trial, a low-calorie soy based meal (240 g/day) was replaced for 12 weeks in humans. After 12 weeks, individuals who received soy meal lost more weight and gained less fat mass, total cholesterol and LDL compared to the control group individuals [34]. The suggested mechanisms involved in the role of soy protein against obesity include reduction in intestinal cholesterol absorption, fecal bile expression, reduced triglyceride concentration, regulating gene expession of lipogenic enzymes and fatty acid oxidation, increased peroxisome proliferator activated receptors (PPARs), modulation of sterol regulating element binding protein (SREBPs) [35]-[40].

\section{Fats and Related Compounds}

Type of fat is more important than the amount in managing certain chronic diseases. Conjugated linoleic acids are isomers of linoleic acid and found mainly in milk, meat and their products of ruminants. Supplementing diet with CLA has reduced body fat accumulation and increased protein content in rats [41]. Short term consumption 
of a spread made with CLAs, induced the expression of lipid metabolizing genes and reduced inflammatory gene expression compared to other fatty acids [42]. Protective mechanisms of CLAs against obesity are increased energy expenditure, decreased energy intake, reduced lipogenesis and enhanced lipolysis, and reduced adipocyte proliferation and differentiation [43]-[46]. The primary mechanism of CLA in fat reduction is through the modulation of transcription factor PPAR $\gamma$, thereby inhibiting the downstream metabolic pathways involved in lipogenesis and adipocyte differentiation [47] [48]. Stearoyl-CoA desaturase-1 (SCD-1), a key enzyme in the regulation of lipid oxidation and hepatic lipogenesis, is one of the targets of obesity management. Administration of isomers of CLAs resulted in either reduced SCD-1 or inhibited the activity in a variety of cells [49].

Weight loss programs emphasize on the consumption of fatty fish to reduce lipid content [50]. Energy restricted diets consists of three servings of fatty fish per week increased leptin levels in obese humans [51]. Consumption of a hypocaloric diet with salmon also improved plasma lipid profile [52]. Administration of polyphenol rich oils to obese men in a randomized cross over study resulted in inhibition of postprandial inflammation [53].

Consumption of soybean, coconut and lard for 60 days reduced serum adiponectin levels as well as gene expresion in mice [54]. Incubating 3T3L1 cells with DHA, EPA, palmitic, and linoleic acids also resulted in a reduced gene expression of adiponectin.

Diacylglycerols (DAG) increases thermogenesis compared to triacylglycerols and therefore have been suggested for weight management. With the consumption of DAG for 14 days, enzymes involved in fatty acid oxidation were increased and synthesis were reduced in rats [55]. After hydrolysis into two fatty acids and a glycerol moiety, DAGs may not be reformed back and enter into circulation as such and be oxidized by liver [56]. Diet of normal weight men was supplemented with $10 \mathrm{~g} / \mathrm{d}$ of either DAG or TAG for 16 weeks to determine the effect of diets on weight loss. Men consumed fats as a part of breakfast in form of bread and mayonnaise. After the study period, a significant weight loss was observed in the individuals with the DAG diet [57].

\section{Fruits and Vegetables}

High consumption of fruits and vegetables has been associated with maintenance of health as they offer protection against various chronic diseases. Varied bioactive components at different levels may be responsible for the offered health protection. In an 8-week nutritional intervention study, obese men and women who received enriched fruits with an energy-restricted regimen resulted in low oxidized LDL and improved antioxidant capacity [58]. Black rasberries contain high anthocyanin levels. Purified black rasberries, but not whole black raspberries, reduced body weight gain, fasting serum glucose, leptin, insulin levels and homeostasis assessment of insulin resistance (HOMA-IR) in mice fed high fat diet [59].

Administration of apple reduced body weight gain, fat deposits and glucose in Wistar rats. These antiobesity properties are due to modulation of genes responsible for lipolysis, adipogenesis and fat oxidation [60]. Apples, with relative high fiber content, lowered plasma lipid content and triacylglycerides in liver, as well as improved oxidative status by producing larger intestinal pool and greater fecal excretion of bile acids in obese rats [61]. Dietary apples also reduced the retroperitoneal and epididymal adipose tissue weights [62].

Bilberries and sea buckthorn (whole, phenolic extract, oil) administered for 30 - 35 days, decreased waist circumference, weight, vascular cell adhesion molecule and intercellular adhesion molecule of overweight and obese women [63]. Bilberry anthocyanidin-enriched extracts inhibited adipocyte differentiation in 3T3L1 cells by inhibiting the adipocyte transcription factors peroxisome proliferator-activated receptor (PPAR) and Sterol regulatory element-binding protein 1c (SREBP1c) and tyrosine residues of IRS1 phosphorylation [64].

Hushbush blueberry powder at 2\% reduced body fat, liver weight, body weight, triglycerides, fasting insulin, abdominal fat mass, but increased adipose and skeletal muscle PPAR activity and affected PPAR transcripts involved in fat and glucose metabolism in obese rats [65]. Blueberry polyphenols suppressed adipocyte differentiation, adipogenesis and cell proliferation [66].

Methanol mango peel extracts inhibited the accumulation of lipid droplets in 3T3L1 cells at a concentration of $50-100 \mu \mathrm{g} / \mathrm{ml}$. Mango pulp extracts did not show any effect in inhibiting lipid content [67]. Administration of mulberry polyphenol water extracts for 12 weeks reduced obesity in hamsters via reducing hepatic fatty acid synthase, 3-hydroxy-3-methylglutaryl-coenzyme A (HMG-CoA) reductase, and dyslipidemia [68]. Concentrated oral plum juice reduced lipid content, increased insulin sensitivity, plasma adiponectin and adipose tissue $\operatorname{PPAR} \gamma$ mRNA expression in insulin-resistant obese Wistar fatty rats [69]. Pomegranates are tropical fruits rich 
in phytochemicals such as ellagitannins, anthocyanins, phenolic acids, and a variety of volatile compounds. Pomegranates exhibited anti-obesity properties in in-vivo and in-vitro studies exhibiting hypoglycaemic activity, increase insulin sensitivity, inhibit $\alpha$-glucosidase enzyme activity, reduce total cholesterol, improve blood lipid profiles, and retard inflammation by modulating PPAR pathways [70].

Bitter gourd is widely available vegetable in Asia and has been attributed to offer protection against diabetes. Bitter gourd was fed at $0.5 \%$ and $5 \%$ levels to $\mathrm{C} 57 \mathrm{BL} / 6$ mice for exploring the effects of bitter gourd on mitochondrial function during the development of obesity associated fatty liver. Feeding of bitter gourd for 16 weeks, resulted in reduced body and tissue weight gain, less hyperglycemia and hyperlipidemia, triglycerides, cholesterol, higher superoxide dismutase activity, lower protein oxidation, modulated mitochondria expression, and less activation of sterol regulatory element binding protein/fatty acid synthase (SREBP-1/FAS) pathway in mice fed with bitter gourd at 5\% compared with the mice fed with a high fat diet. Inflammatory markers, serum interleukin-6 and serum C-reactive protein concentration was lower in mice fed with 5\% bitter gourd fed group. Bitter melon modulated fatty acid and glucose transport into adipose and skeletal tissues by regulating adiponectin, AMPK release, insulin secretion, and uncoupling protein elevation [71].

Kochujang, fermented soybean-based red pepper paste, administration to humans at $32 \mathrm{~g} /$ day for 12 weeks reduced visceral body fat, but not body weight and waist to hip ratio [72]. On the contrary, Kochujang reduced differentiation of 3T3L1 adipocytes by inhibiting transcription factors SREBP-1c and PPAR- $\gamma$, and stimulated lipolysis by upregulating hormone sensitive lipase [73].

Piper sarmentosum, edible medicinal plant, administered at $125 \mathrm{mg} / \mathrm{kg} /$ day for 12 weeks reduces visceral fat and inhibits $11 \beta$-hydroxysteroid dehydrogenase type 1 that regulates cortisol metabolism in adipose tissue, to hinder visceral obesity and metabolic disorders [74].

Administration of green tomato extract to mice fed with a high fat diet reduced obesity by activating AMPK and acetyl-CoA carboxylase phosphorylation in the liver. Green tomato decreased epididymal adipose tissue, liver weights, liver cholesterol and serum cholesterol levels. Green tomato extract also decreased the liver HMG-CoA reductase expression, PPAR $\gamma$ (PPAR gamma), CCAAT/enhancer-binding protein alpha and perilipin in the adipose tissue [75].

Onion peel tea (OPT), high in polyphenols, exhibited anti-obesity properties in high fat diet induced obese (BALB/c) mice. Mice were fed with onion peel tea for 28 days after induction of obesity by feeding a high fat diet for 3 weeks. OPT suppressed increase in body weight and level of epididymal fat tissue, reduced serum concentrations of total cholesterol, glucose and leptin [76].

\section{Beverages}

Tea (Camellia sinensis) is a widely consumed beverage around world. Green tea is unfermented and is rich of polyphenolic compounds. Oolong tea is partially oxidized and possess considerable amounts of polyphenols. Black tea is fermented and contains mostly thoeflavins and polyphenols. Black Tea polyphenols are reported to inhibit pancreatic lipase and thereby effect lipid metabolism [77].

Caffeine present in tea was shown to have thermogenic effects and stimulate fat oxidation. Caffeine and polyphenols in tea act additively to effect fat oxidation [78]. A significant increase in $24 \mathrm{~h}$ energy expenditure was reported after consumption of thermogenic beverage $(250 \mathrm{ml})$ three times/day for 3 days contains $94 \mathrm{mg}$ EGCG and $100 \mathrm{mg}$ caffeine [79]. Caffeine consumed at $100 \mathrm{mg}$ per serving increased basal metabolic rate by $3 \%-4 \%$ and energy expenditure in a $2 \mathrm{hr}$ period by $16 \%$ in both in lean and obese individuals [80]. In studies conducted with green tea (576 - $592.2 \mathrm{mg}$ catechins), an increase in fat oxidation, reduction in body fat ratio and waist circumference [81] [82] were observed. Mechanisms proposed for the action of green tea in increasing energy expenditure are inhibiting catechol O-methytransferase (COMT) enzyme which degrades norepinephrine, inhibiting enzyme phosphodiesterase which degrades intracellular cAMP, antagonizes the inhibitory effects of adenosine on lipolysis, increased expression of uncoupling proteins, and activation of PPARs [83]-[86].

Supplementation of cocoa powder at $8 \%$ to high fat fed C57BL/6J mice reduced body weight gain, increased fecal fat content, improved insulin sensitivity, inflammation and down-regulated the pro-inflammatory gene expression [87]. Yang et al. [88] also reported that feeding 2\% - 4\% cocoa extract to C57BL/6 mice reduced weight gain, fat pad mass, liver weight, lipid content and triglycreride content. Coffee polyphenols (mono- or di-caffeoyl quinic acids (CQA)) inhibited lipogenesis by downregulating sterol regulatory element-binding protein (SREBP-1c), acetyl-CoA carboxylase-1 and -2, stearoyl-CoA desaturase-1 and pyruvate dehydrogenase ki- 
nase-4 in the liver and also reduced infiltration of macrophages into the fat tissues [89]. Murase et al. [90] investigated the effect of coffee polyphenols (CPP) in modulating postprandial macronutrient (carbohydrate, lipid) metabolism and whole-body substrate oxidation in C57BL/6J mice with a lipid-carbohydrate (sucrose or starch)mixed emulsion. CPP suppressed postprandial plasma glucose, insulin, glucose-dependent insulinotropic polypeptide (GIP), and triacyl glyceride (TAG) levels.

A novel antioxidant beverage was prepared from the coffee silverskin of Arabic (Coffea Arabica) and Robusta (Coffea canephora) varieties and tested for their antiobesity potential employing the Caenorhabditis elegans model. All tested concentrations of both extracts $(25,50$ and $100 \mu \mathrm{g} / \mathrm{ml})$ increased body fat reducing phenotypes. The highest effective dose was $100 \mu \mathrm{g} / \mathrm{ml}$ of Arabic extract, which accounts for $10 \mathrm{mg} / \mathrm{ml}$ of coffee silverskin. The dose of active compounds present in extracts, caffeine and chlorogenic acid, are relative to physiological dose and may offer protection against obesity [91].

Anthocyanin rich juices Blueberry Juice (BBJ) and Mulberry Juice (MBJ) were tested for their effect in offering protection against obesity in high fat fed C57BL/6 mice. Juices reduced body weight ( $7 \%-10 \%)$, epididymal fat and size of fat cells. Serum glucose and cholesterol level were lowered by BBJ, but not by MBJ. Juices altered lipid metabolism by suppressing fatty acid synthesis related genes (PPAR $\gamma$ and FAS) and inducing the expression of $\beta$-oxidation-related gene (CPT 1) [92].

Noni Juice is rich in phenolic acids: gentisic, and chlorogenic acids. Feeding noni juice at 3, 6, $9 \mathrm{mg} / \mathrm{kg}$ body wt for six weeks to hamsters decreased liver and visceral fat accumulation, and serum lipids. Juice administration increased the fecal lipid/bile content. Juices also increased the liver antioxidant capacities and lowered inflammatory protein (TNF-a, IL-1b, iNOS, and COX-2, MMP9) expression [93].

\section{Calcium and Dairy Products}

Low intake of dairy products and calcium is inversely related to adiposity [94]. Dietary calcium plays an important role in regulation of energy metabolism and obesity risk [95]. Dairy products are the main source of dietary calcium and different mechanisms have been proposed for explaining the role of calcium. Chronic increase in dietary calcium reduces intracellular calcium in adipocytes, thereby reduces expression of fatty acid synthase, enzyme required for lid synthesis. The potential hypolipidemic mechanisms of calcium may occur at GI tract via inhibition of fat absorption, increased fecal fat excretion, inhibition of bile acid absorption, a calcium-induced increase in the conversion of cholesterol to bile acids [96].

\section{Conclusion}

Development of obesity is through the effect of various complex pathways. There is a need to target many processes rather than single process or target. Although the available research supports evidence for the potential to develop functional foods, the real challenge for the food industry is to develop products that are effective by having multiple mechanisms. The other challenge to develop functional foods for obesity is the lack of potential biomarkers to test the compounds. Studies should focus on determining the optimum level of intake, efficacy and safety of products for long-term consumption.

\section{References}

[1] Ogden, C.L., Carroll, M.D., Kit, B.K. and Flegal, K.M. (2014) Prevalence of Childhood and Adult Obesity in the United States, 2011-2012. JAMA, 311, 806-814. http://dx.doi.org/10.1001/jama.2014.732

[2] Keats, S. and Wiggins, S. (2014) The Overseas Development Institute (ODI). Future Diets: Implications for Agriculture and Food Prices. http://www.odi.org.uk/sites/odi.org.uk/files/odi-assets/publications-opinion-files/8776.pdf

[3] Finkelstein, E.A., Trogdon, J.G., Cohen, J.W. and Dietz, W. (2009) Annual Medical Spending Attributable to Obesity: Payer- and Service-Specific Estimates. Health Affairs (Millwood), 5, 822-831. http://dx.doi.org/10.1377/hlthaff.28.5.w822

[4] Dolgin, E. (2012) A History of Drugs on the Weight List. Nature Medicine, 18, 843. http://dx.doi.org/10.1038/nm0612-843

[5] Miller, L.E. (2013) Lorcaserin for Weight Loss: Insights into US Food and Drug Administration Approval. Journal of the Academy of Nutrition and Dietetics, 113, 25-30. http://dx.doi.org/10.1016/j.jand.2012.08.028

[6] Berthoud, H.R., Lenard, N.R. and Shin, A.C. (2011) Food Reward, Hyperphagia, and Obesity. American Journal of Physiology-Regulatory, Integrative and Comparative Physiology, 300, R1266-R1277. 
http://dx.doi.org/10.1152/ajpregu.00028.2011

[7] Davidson, T.L. and Swithers, S.E. (2004) A Pavlovian Approach to the Problem of Obesity. International Journal of Obesity, 28, 933-935. http://dx.doi.org/10.1038/sj.ijo.0802660

[8] Bigliardi, B. and Galati, F. (2013) Innovation Trends in the Food Industry: The Case of Functional Foods. Trends in Food Science and Technology, 31, 118-129. http://dx.doi.org/10.1016/j.tifs.2013.03.006

[9] Anonymous (2005) Functional Foods: Opportunities and Challenges. IFT Expert Report, Institute of Food Technologists. http://www.ift.org/ /media/Knowledge\%20Center/Science\%20Reports/Expert\%20Reports/Functional\%20Foods/Funct ionalfoods_expertreport_full.pdf

[10] Ostrowska, L., Fiedorczuk, J. and Adamska, E. (2013) Effect of Diet and Other Factors on Serum Adiponectin Concentrations in Patients with Type 2 Diabetes. Roczniki Panstwowego Zakladu Higieny, 64, 61-66.

[11] Wynne, K., Stanley, S., McGowan, B. and Bloom, S. (2005) Appetite Control. Journal of Endocrinology, 184, 291318. http://dx.doi.org/10.1677/joe.1.05866

[12] Serrano, J.C., Cassanyé, A. and Portero-Otin, M. (2012) Trends in Functional Food against Obesity. In: Valdez, B., Ed., Scientific, Health and Social Aspects of the Food Industry, 279-294.

[13] Sergent, T., Vanderstraeten, J., Winand, J., Beguin, P. and Schneider, Y.J. (2012) Phenolic Compounds and Plant Extracts as Potential Natural Anti-Obesity Substances. Food Chemistry, 135, 68-73. http://dx.doi.org/10.1016/j.foodchem.2012.04.074

[14] Dalar, A. and Konczak, I. (2013) Phenolic Contents, Antioxidant Capacities and Inhibitory Activities against Key Metabolic Syndrome Relevant Enzymes of Herbal Teas from Eastern Anatolia. Industrial Crops and Products, 44, 383390. http://dx.doi.org/10.1016/j.indcrop.2012.11.037

[15] Murase, T., Yokoi, Y., Misawa, K., Ominami, H., Suzuki, Y., Shibuya, Y. and Hase, T. (2012) Coffee Polyphenols Modulate Whole-Body Substrate Oxidation and Suppress Postprandial Hyperglycaemia, Hyperinsulinaemia and Hyperlipidaemia. British Journal of Nutrition, 107, 1757-1765. http://dx.doi.org/10.1017/S0007114511005083

[16] Rayalam, S., Della-Fera, M.A. and Baile, C.A. (2008) Phytochemicals and Regulation of the Adipocyte Life Cycle. The Journal of Nutritional Biochemistry, 19, 717-726. http://dx.doi.org/10.1016/j.jnutbio.2007.12.007

[17] Hirai, S., Takahashi, N., Goto, T., Lin, S., Uemura, T., Yu, R. and Kawada, T. (2010) Functional Food Targeting the Regulation of Obesity-Induced Inflammatory Responses and Pathologies. Mediators of Inflammation, 2010, Article ID: 367838. http://dx.doi.org/10.1155/2010/367838

[18] Kozuka, C., Yabiku, K., Sunagawa, S., Ueda, R., Taira, S.I., Ohshiro, H., Masuzaki, H., et al. (2012) Brown Rice and Its Component, $\gamma$-Oryzanol, Attenuate the Preference for High-Fat Diet by Decreasing Hypothalamic Endoplasmic Reticulum Stress in Mice. Diabetes, 61, 3084-3093. http://dx.doi.org/10.2337/db11-1767

[19] Scribner, K.B., Pawlak, D.B. and Ludwig, D.S. (2007) Hepatic Steatosis and Increased Adiposity in Mice Consuming Rapidly vs. Slowly Absorbed Carbohydrate. Obesity, 15, 2190-2199. http://dx.doi.org/10.1038/oby.2007.260

[20] Scribner, K.B., Pawlak, D.B., Aubin, C.M., Majzoub, J.A. and Ludwig, D.S. (2008) Long-Term Effects of Dietary Glycemic Index on Adiposity, Energy Metabolism, and Physical Activity in Mice. American Journal of PhysiologyEndocrinology and Metabolism, 295, E1126-E1131. http://dx.doi.org/10.1152/ajpendo.90487.2008

[21] Gao, Z., Yin, J., Zhang, J., Ward, R.E., Martin, R.J., Lefevre, M., Cefalu, W.T. and Ye, J.P. (2009) Butyrate Improves Insulin Sensitivity and Increases Energy Expenditure in Mice. Diabetes, 58, 1509-1517. http://dx.doi.org/10.2337/db08-1637

[22] Beauvieux, M.C., Roumes, H., Robert, N., Gin, H., Rigalleau, V. and Gallis, J.L. (2008) Butyrate Ingestion Improves Hepatic Glycogen Storage in the Re-Fed Rat. BMC Physiology, 8, 19. http://dx.doi.org/10.1186/1472-6793-8-19

[23] Larsen, T.M., Dalskov, S.M., van Baak, M., Jebb, S.A., Papadaki, A., Pfeiffer, A.F., Astrup, A., et al. (2010) Diets with High or Low Protein Content and Glycemic Index for Weight-Loss Maintenance. New England Journal of Medicine, 363, 2102-2113. http://dx.doi.org/10.1056/NEJMoa1007137

[24] Keller, U. (2011) Dietary Proteins in Obesity and Diabetes. International Journal of Vitamins and Nutrition Research, 81, 125-133.

[25] Anderson, G.H. and Moore, S.E. (2004) Dietary Proteins in the Regulation of Food Intake and Body Weight in Humans. The Journal of Nutrition, 134, 974S-979S.

[26] Krebs, M., Brehm, A., Krssak, M., Anderwald, C., Bernroider, E., Nowotny, P., Roth, E., Chandramouli, V., Landau, B.R., Waldh, W. and Roden, M. (2003) Direct and Indirect Effects of Amino Acids on Hepatic Glucose Metabolism in Humans. Diabetologia, 46, 917-925. http://dx.doi.org/10.1007/s00125-003-1129-1

[27] Crujeiras, A.B., Parra, D., Abete, I. and Martínez, J.A. (2007) A Hypocaloric Diet Enriched in Legumes Specifically Mitigates Lipid Peroxidation in Obese Subjects. Free Radical Research, 41, 498-506. 
http://dx.doi.org/10.1080/10715760601131935

[28] Abete, I., Parra, D. and Martinez, J.A. (2008) Energy-Restricted Diets Based on a Distinct Food Selection Affecting the Glycemic Index Induce Different Weight Loss and Oxidative Response. Clinical Nutrition Supplements, 27, 545551. http://dx.doi.org/10.1016/j.clnu.2008.01.005

[29] Dave, S., Kaur, N.J., Nanduri, R., Dkhar, H.K., Kumar, A. and Gupta, P. (2012) Inhibition of Adipogenesis and Induction of Apoptosis and Lipolysis by Stem Bromelain in 3T3-L1 Adipocytes. PLoS ONE, 7, Article ID: e30831. http://dx.doi.org/10.1371/journal.pone.0030831

[30] Iwashita, S., Mikus, C., Baier, S. and Flakoll, P.J. (2006) Glutamine Supplementation Increases Postprandial Energy Expenditure and Fat Oxidation in Humans. Journal of Parenteral and Enteral Nutrition, 30, 76-80. http://dx.doi.org/10.1177/014860710603000276

[31] Yang, Y., Zhou, L., Gu, Y., Zhang, Y., Tang, J., Li, F., Shang, W., Jiang, B., Yue, X. and Chen, M. (2007) Dietary Chickpeas Reverse Visceral Adiposity, Dyslipidaemia and Insulin Resistance in Rats Induced by a Chronic High-Fat Diet. British Journal of Nutrition, 98, 720-726.

[32] Kwak, J.H., Ahn, C.W., Park, S.H., Jung, S.U., Min, B.J., Kim, O.Y. and Lee, J.H. (2012) Weight Reduction Effects of a Black Soy Peptide Supplement in Overweight and Obese Subjects: Double Blind, Randomized, Controlled Study. Food \& Function, 3, 1019-1024.

[33] Nagasawa, A., Fukui, K., Funahashi, T., Maeda, N., Shimomura, I., Kihara, S., Waki, M., Takamatsu, K. and Matsuzawa, Y. (2002) Effects of Soy Protein Diet on the Expression of Adipose Genes and Plasma Adiponectin. Hormone and Metabolic Research, 34, 635-639. http://dx.doi.org/10.1055/s-2002-38254

[34] Allison, D.B., Gadbury, G., Schwartz, L.G., Murugesan, R., Kraker, J.L., Heshka, S., Fontaine, K.R. and Heymsfield, S.B. (2003) A Novel Soy-Based Meal Replacement Formula for Weight Loss among Obese Individuals: A Randomized Controlled Clinical Trial. European Journal of Clinical Nutrition, 57, 514-522. http://dx.doi.org/10.1038/sj.ejcn.1601587

[35] Wright, S.M. and Salter, A.M. (1998) Effects of Soy Protein on Plasma Cholesterol and Bile Acid Excretion in Hamsters. Comparative Biochemistry and Physiology Part B: Biochemistry and Molecular Biology, 119, 247-254. http://dx.doi.org/10.1016/S0305-0491(97)00288-5

[36] Dyck, J., Berthiaume, L., Thomas, P., Kantor, P., Barr, A., Barr, R., Prentki, M., et al. (2000) Characterization of Rat Liver Malonyl-CoA Decarboxylase and the Study of Its Role in Regulating Fatty Acid Metabolism. Biochemical Journal, 350, 599-608. http://dx.doi.org/10.1042/0264-6021:3500599

[37] Xiao, C.W., Wood, C., Huang, W., Abbé, M.R., Gilani, G.S., Gerard, M.C. and Curran, I. (2006) Tissue-Specific Regulation of Acetyl-CoA Carboxylase Gene Expression by Dietary Soya Protein Isolate in Rats. British Journal of Nutrition, 95, 1048-1054. http://dx.doi.org/10.1079/BJN20061776

[38] Mezei, O., Banz, W.J., Steger, R.W., Peluso, M.R., Winters, T.A. and Shay, N. (2003) Soy Isoflavones Exert Antidiabetic and Hypolipidemic Effects through the PPAR Pathways in Obese Zucker Rats and Murine RAW 264.7 Cells. The Journal of Nutrition, 133, 1238-1243.

[39] Duranti, M., Lovati, M.R., Dani, V., Barbiroli, A., Scarafoni, A., Castiglioni, S., Ponzone, C. and Morazzoni, P. (2004) The $\alpha$ ' Subunit from Soybean 7S Globulin Lowers Plasma Lipids and Upregulates Liver $\beta$-VLDL Receptors in Rats Fed a Hypercholesterolemic Diet. The Journal of Nutrition, 134, 1334-1339.

[40] Velasquez, M.T. and Bhathena, S.J. (2007) Role of Dietary Soy Protein in Obesity. International Journal of Medical Sciences, 4, 72-82. http://dx.doi.org/10.7150/ijms.4.72

[41] Akahoshi, A., Koba, K., Ichinose, F., Kaneko, M., Shimoda, A., Nonaka, K., Yamasaki, M., Iwata, T., Yamauchi, Y., Tsutsumi, K. and Sugano, M. (2004) Dietary Protein Modulates the Effect of CLA on Lipid Metabolism in Rats. Lipids, 39, 25-30. http://dx.doi.org/10.1007/s11745-004-1197-3

[42] Van Erk, M.J., Pasman, W.J., Wortelboer, H.M., Van Ommen, B. and Hendriks, H.F. (2008) Short-Term Fatty Acid Intervention Elicits Differential Gene Expression Responses in Adipose Tissue from Lean and Overweight Men. Genes \& Nutrition, 3, 127-137. http://dx.doi.org/10.1007/s12263-008-0096-z

[43] Evans, M., Geigerman, C., Cook, J., Curtis, L., Kuebler, B. and McIntosh, M. (2000) Conjugated Linoleic Acid Suppresses Triglyceride Accumulation and Induces Apoptosis in 3T3-L1 Preadipocytes. Lipids, 35, 899-910. http://dx.doi.org/10.1007/S11745-000-0599-6

[44] Lin, X., Loor, J.J. and Herbein, J.H. (2004) Trans10,cis12-18:2 Is a More Potent Inhibitor of de Novo Fatty Acid Synthesis and Desaturation than Cis9,trans11-18:2 in the Mammary Gland of Lactating Mice. The Journal of Nutrition, 134, 1362-1368.

[45] Ostrowska, E., Cross, R.F., Muralitharan, M., Bauman, D.E. and Dunshea, F.R. (2002) Effects of Dietary Fat and Conjugated Linoleic Acid on Plasma Metabolite Concentrations and Metabolic Responses to Homeostatic Signals in Pigs. British Journal of Nutrition, 88, 625-634. http://dx.doi.org/10.1079/BJN2002726 
[46] Salas-Salvado, J., Marquez-Sandoval, F. and Bullo, M. (2006) Conjugated Linoleic Acid Intake in Humans: A Systematic Review Focusing on Its Effect on Body Composition, Glucose, and Lipid Metabolism. Critical Reviews in Food Science and Nutrition, 46, 479-488. http://dx.doi.org/10.1080/10408390600723953

[47] Ding, S.T., McNeel, R.L. and Mersmann, H.J. (2002) Modulation of Adipocyte Determination and DifferentiationDependent Factor 1 by Selected Polyunsaturated Fatty Acids. In Vitro Cellular \& Developmental Biology-Animal, 38, 352-357. http://dx.doi.org/10.1290/1071-2690(2002)038<0352:MOADAD>2.0.CO;2

[48] Brown, J.M., Boysen, M.S., Chung, S., Fabiyi, O., Morrison, R.F., Mandrup, S. and McIntosh, M.K. (2004) Conjugated Linoleic Acid Induces Human Adipocyte Delipidation Autocrine/Paracrine Regulation of MEK/ERK Signalling by Adipocytokines. Journal of Biological Chemistry, 279, 26735-26747. http://dx.doi.org/10.1074/jbc.M401766200

[49] Brown, J.M. and McIntosh, M.K. (2003) Conjugated Linoleic Acid in Humans: Regulation of Adiposity and Insulin Sensitivity. The Journal of Nutrition, 133, 3041-3046.

[50] Mori, T.A., Burke, V., Puddey, I.B., Shaw, J.E. and Beilin, L.J. (2004) Effect of Fish Diets and Weight Loss on Serum Leptin Concentration in Overweight, Treated-Hypertensive Subjects. Journal of Hypertension, 22, 1983-1990. http://dx.doi.org/10.1097/00004872-200410000-00022

[51] Abete, I., Parra, D., Crujeiras, A., Goyenechea, E. and Martinez, J. (2008) Specific Insulin Sensitivity and Leptin Responses to a Nutritional Treatment of Obesity via a Combination of Energy Restriction and Fatty Fish Intake. Journal of Human Nutrition and Dietetics, 21, 591-600. http://dx.doi.org/10.1111/j.1365-277X.2008.00902.x

[52] Marques, M., Parra, D., Kiely, M., Bandarra, N., Thorsdottir, I. and Martinez, J.A. (2008) Omega-3 Fatty Acids Inclusion as Part of an Energy Restricted Diet to Improve the Effect on Blood Lipids. Medicina Clínica, 130, 10-12.

[53] Perez-Herrera, A., Delgado-Lista, J., Torres-Sanchez, L., Rangel-Zuñiga, O., Camargo, A., Moreno-Navarrete, J., MuñozLopez, C., et al. (2012) The Postprandial Inflammatory Response after Ingestion of Heated Oils in Obese Persons Is Reduced by the Presence of Phenol Compounds. Molecular Nutrition \& Food Research, 56, 510-514. http://dx.doi.org/10.1002/mnfr.201100533

[54] Bueno, A.A., Oyama, L.M., De Oliveira, C., Pisani, L.P., Ribeiro, E.B., Silveira, V.L.F. and Do Nascimento, C.M.O. (2008) Effects of Different Fatty Acids and Dietary Lipids on Adiponectin Gene Expression in 3T3-L1 Cells and C57BL/6J Mice Adipose Tissue. Pflügers Archiv-European Journal of Physiology, 455, 701-709. http://dx.doi.org/10.1007/s00424-007-0330-3

[55] Murata, M., Ide, T. and Hara, K. (1997) Reciprocal Responses to Dietary Diacylglycerol of Hepatic Enzymes of Fatty Acid Synthesis and Oxidation in the Rat. British Journal of Nutrition, 77, 107-121. http://dx.doi.org/10.1079/BJN19970013

[56] Murata, M., Hara, K. and Ide, T. (1994) Alteration by Diacylglycerols of the Transport and Fatty Acid Composition of Lymph Chylomicrons in Rats. Bioscience, Biotechnology, and Biochemistry, 58, 1416-1419. http://dx.doi.org/10.1271/bbb.58.1416

[57] Nagao, T., Watanabe, H., Goto, N., Onizawa, K., Taguchi, H., Matsuo, N., Yasukawa, T., Tsushima, R., Shimasaki, H. and Itakura, H. (2000) Dietary Diacylglycerol Suppresses Accumulation of Body Fat Compared to Triacylglycerol in Men in a Double-Blind Controlled Trial. Journal of Nutrition, 130, 792-797.

[58] Crujeiras, A.B., Parra, M.D., Rodríguez, M.C., Martínez de Morentin, B.E. and Martínez, J.A. (2006) A Role for Fruit Content in Energy-Restricted Diets in Improving Antioxidant Status in Obese Women during Weight Loss. Nutrition, 22, 593-599. http://dx.doi.org/10.1016/j.nut.2006.03.008

[59] Prior, R.L., Wilkes, S.E., Rogers, T.R., Khanal, R.C., Wu, X. and Howard, L.R. (2010) Purified Blueberry Anthocyanins and Blueberry Juice Alter Development of Obesity in Mice Fed an Obesogenic High-Fat Diet. Journal of Agricultural and Food Chemistry, 58, 3970-3976. http://dx.doi.org/10.1021/jf902852d

[60] Boqué, N., Iglesia, R., Garza, A.L., Milagro, F.I., Olivares, M., Bañuelos, Ó., Soria, A.C., Rodríguez-Sánchez, S., Martínez, J.A. and Campión, J. (2013) Prevention of Diet-Induced Obesity by Apple Polyphenols in Wistar Rats through Regulation of Adipocyte Gene Expression and DNA Methylation Patterns. Molecular Nutrition \& Food Research, 57, 1473-1478. http://dx.doi.org/10.1002/mnfr.201200686

[61] Aprikian, O., Duclos, V., Guyot, S., Besson, C., Manach, C., Bernalier, A., Morand, C., Rémésy, C. and Demigné, C. (2003) Apple Pectin and a Polyphenol-Rich Apple Concentrate Are More Effective Together than Separately on Cecal Fermentations and Plasma Lipids in Rats. The Journal of Nutrition, 133, 1860-1865.

[62] Nakazato, K., Song, H. and Waga, T. (2006) Effects of Dietary Apple Polyphenol on Adipose Tissues Weights in Wistar Rats. Experimental Animals/Japanese Association for Laboratory Animal Science, 55, 383-389. http://dx.doi.org/10.1538/expanim.55.383

[63] Lehtonen, H.M., Suomela, J.P., Tahvonen, R., Yang, B., Venojärvi, M., Viikari, J. and Kallio, H. (2011) Different Berries and Berry Fractions Have Various but Slightly Positive Effects on the Associated Variables of Metabolic Diseases on Overweight and Obese Women. European Journal of Clinical Nutrition, 65, 394-401. http://dx.doi.org/10.1038/ejcn.2010.268 
[64] Suzuki, R., Tanaka, M., Takanashi, M., Hussain, A., Yuan, B., Toyoda, H. and Kuroda, M. (2011) AnthocyanidinsEnriched Bilberry Extracts Inhibit 3T3-L1 Adipocyte Differentiation via the Insulin Pathway. Nutrition \& Metabolism, 8, 14. http://dx.doi.org/10.1186/1743-7075-8-14

[65] Seymour, E.M., Tanone, I.I., Urcuyo-Llanes, D.E., Lewis, S.K., Kirakosyan, A., Kondoleon, M.G., Kaufman, P.B. and Bolling, S.F. (2011) Blueberry Intake Alters Skeletal Muscle and Adipose Tissue Peroxisome Proliferator-Activated Receptor Activity and Reduces Insulin Resistance in Obese Rats. Journal of Medicinal Food, 14, 1511-1518. http://dx.doi.org/10.1089/jmf.2010.0292

[66] Moghe, S.S., Juma, S., Imrhan, V. and Vijayagopal, P. (2012) Effect of Blueberry Polyphenols on 3T3-F442A Preadipocyte Differentiation. Journal of Medicinal Food, 15, 448-452. http://dx.doi.org/10.1089/jmf.2011.0234

[67] Taing, M.W., Pierson, J.T., Hoang, V.L., Shaw, P.N., Dietzgen, R.G., Gidley, M.J., Roberts-Thomson, S.J. and Monteith, G.R. (2012) Mango Fruit Peel and Flesh Extracts Affect Adipogenesis in 3T3-L1 Cells. Food \& Function, 3, 828-836. http://dx.doi.org/10.1039/c2fo30073g

[68] Peng, C.H., Liu, L.K., Chuang, C.M., Chyau, C.C., Huang, C.N. and Wang, C.J. (2011) Mulberry Water Extracts Possess an Anti-Obesity Effect and Ability to Inhibit Hepatic Lipogenesis and Promote Lipolysis. Journal of Agricultural and Food Chemistry, 59, 2663-2671. http://dx.doi.org/10.1021/jf1043508

[69] Utsunomiya, H., Yamakawa, T., Kamei, J., Kadonosono, K. and Tanaka, S. (2005) Anti-Hyperglycemic Effects of Plum in a Rat Model of Obesity and Type 2 Diabetes, Wistar Fatty Rat. Biomedical Research (Tokyo, Japan), 26, 193200. http://dx.doi.org/10.2220/biomedres.26.193

[70] Medjakovic, S. and Jungbauer, A. (2013) Pomegranate: A Fruit That Ameliorates Metabolic Syndrome. Food \& Function, 4, 19-39. http://dx.doi.org/10.1039/c2fo30034f

[71] Chaturvedi, P. (2012) Antidiabetic Potentials of Momordica charantia: Multiple Mechanisms behind the Effects. Journal of Medicinal Food, 15, 101-107. http://dx.doi.org/10.1089/jmf.2010.0258

[72] Cha, Y.S., Kim, S.R., Yang, J.A., Back, H.I., Kim, M.G., Jung, S.J., Song, W.O. and Chae, S.W. (2013) Kochujang, Fermented Soybean-Based Red Pepper Paste, Decreases Visceral Fat and Improves Blood Lipid Profiles in Overweight Adults. Nutrition \& Metabolism, 10, 24. http://dx.doi.org/10.1186/1743-7075-10-24

[73] Ahn, J., Jang, H.S., Song, Y.J., Yang, T.H. and Jahng, K.Y. (2011) Occurrence and Biotransformation of Ochratoxin a during Pepper Sauce Fermentation. Journal of the Korean Society for Applied Biological Chemistry, 54, 972-977. http://dx.doi.org/10.1007/BF03253188

[74] Fairus, A., Ima, N.S., Elvy, S.M., Tan, M.H., Santhana, R. and Farihah, H.S. (2013) Piper Sarmentosum Is Comparable to Glycyrrhizic Acid in Reducing Visceral Fat Deposition in Adrenalectomised Rats Given Dexamethasone. La Clinica Terapeutica, 164, 5-10.

[75] Choi, K.M., Lee, Y.S., Shin, D.M., Lee, S., Yoo, K.S., Lee, M.K., Yoo, H.S., et al. (2013) Green Tomato Extract Attenuates High-Fat-Diet-Induced Obesity through Activation of the AMPK Pathway in C57BL/6 Mice. The Journal of Nutritional Biochemistry, 24, 335-342. http://dx.doi.org/10.1016/j.jnutbio.2012.06.018

[76] Matsunaga, S., Azuma, K., Watanabe, M., Tsuka, T., Imagawa, T., Osaki, T. and Okamoto, Y. (2014) Onion Peel Tea Ameliorates Obesity and Affects Blood Parameters in a Mouse Model of High-Fat-Diet-Induced Obesity. Experimental and Therapeutic Medicine, 7, 379-382.

[77] Yuda, N., Tanaka, M., Suzuki, M., Asano, Y., Ochi, H. and Iwatsuki, K. (2012) Polyphenols Extracted from Black Tea (Camellia sinensis) Residue by Hot-Compressed Water and Their Inhibitory Effect on Pancreatic Lipase in Vitro. Journal of Food Science, 77, H254-H261. http://dx.doi.org/10.1111/j.1750-3841.2012.02967.x

[78] Dulloo, A.G., Duret, C., Rohrer, D., Girardier, L., Mensi, N., Fathi, M., Chantre, P. and Vandermander, J. (1999) Efficacy of a Green Tea Extract Rich in Catechin Polyphenols and Caffeine in Increasing 24-h Energy Expenditure and Fat Oxidation in Humans. The American Journal of Clinical Nutrition, 70, 1040-1045.

[79] Rudelle, S., Ferruzzi, M.G., Cristiani, I., Moulin, J., Macé, K., Acheson, K.J. and Tappy, L. (2007) Effect of a Thermogenic Beverage on 24-Hour Energy Metabolism in Humans. Obesity, 15, 349-355. http://dx.doi.org/10.1038/oby.2007.529

[80] Hollands, M.A., Arch, J.R. and Cawthorne, M.A. (1981) A Simple Apparatus for Comparative Measurements of Energy Expenditure in Human Subjects: The Thermic Effect of Caffeine. The American Journal of Clinical Nutrition, 34, 2291-2294.

[81] Matsuyama, T., Tanaka, Y., Kamimaki, I., Nagao, T. and Tokimitsu, I. (2008) Catechin Safely Improved Higher Levels of Fatness, Blood Pressure, and Cholesterol in Children. Obesity, 16, 1338-1348. http://dx.doi.org/10.1038/oby.2008.60

[82] Kovacs, E.M., Lejeune, M.P., Nijs, I. and Westerterp-Plantenga, M.S. (2004) Effects of Green Tea on Weight Maintenance after Body-Weight Loss. British Journal of Nutrition, 91, 431-437. http://dx.doi.org/10.1079/BJN20041061

[83] Westerterp-Plantenga, M.S. (2010) Green Tea Catechins, Caffeine and Body-Weight Regulation. Physiology \& Beha- 
vior, 100, 42-46. http://dx.doi.org/10.1016/j.physbeh.2010.02.005

[84] Westerterp-Plantenga, M.S., Lejeune, M.P. and Kovacs, E.M. (2005) Body Weight Loss and Weight Maintenance in Relation to Habitual Caffeine Intake and Green Tea Supplementation. Obesity Research, 13, 1195-1204. http://dx.doi.org/10.1038/oby.2005.142

[85] Cornelis, M.C. and El-Sohemy, A. (2007) Coffee, Caffeine, and Coronary Heart Disease. Current Opinion in Lipidology, 18, 13-19. http://dx.doi.org/10.1097/MOL.0b013e3280127b04

[86] Murase, T., Nagasawa, A., Suzuki, J., Hase, T. and Tokimitsu, I. (2002) Beneficial Effects of Tea Catechins on DietInduced Obesity: Stimulation of Lipid Catabolism in the Liver. International Journal of Obesity, 26, 1459-1464. http://dx.doi.org/10.1038/sj.ijo.0802141

[87] Gu, Y., Yu, S. and Lambert, J.D. (2014) Dietary Cocoa Ameliorates Obesity-Related Inflammation in High Fat-Fed Mice. European Journal of Nutrition, 53, 149-158. http://dx.doi.org/10.1007/s00394-013-0510-1

[88] Yang, X.R., Wat, E., Wang, Y.P., Ko, C.H., Koon, C.M., Siu, W.S., Leung, P.C., et al. (2013) Effect of Dietary Cocoa Tea (Camellia ptilophylla) Supplementation on High-Fat Diet-Induced Obesity, Hepatic Steatosis, and Hyperlipidemia in Mice. Evidence-Based Complementary and Alternative Medicine, 2013, Article ID: 783860. http://dx.doi.org/10.1155/2013/783860

[89] Murase, T., Misawa, K., Minegishi, Y., Aoki, M., Ominami, H., Suzuki, Y., Shibuya, Y. and Hase, T. (2011) Coffee Polyphenols Suppress Diet-Induced Body Fat Accumulation by Downregulating SREBP-1c and Related Molecules in C57BL/6J Mice. American Journal of Physiology-Endocrinology and Metabolism, 300, E122-E133. http://dx.doi.org/10.1152/ajpendo.00441.2010

[90] Murase, T., Yokoi, Y., Misawa, K., Ominami, H., Suzuki, Y., Shibuya, Y. and Hase, T. (2012) Coffee Polyphenols Modulate Whole-Body Substrate Oxidation and Suppress Postprandial Hyperglycaemia, Hyperinsulinaemia and Hyperlipidaemia. British Journal of Nutrition, 107, 1757-1765. http://dx.doi.org/10.1017/S0007114511005083

[91] Martinez-Saez, N., Ullate, M., Martin-Cabrejas, M.A., Martorell, P., Genovés, S., Ramon, D. and Del Castillo, M.D. (2014) A Novel Antioxidant Beverage for Body Weight Control Based on Coffee Silverskin. Food Chemistry, 150, 227-234. http://dx.doi.org/10.1016/j.foodchem.2013.10.100

[92] Wu, T., Qi, X., Liu, Y., Guo, J., Zhu, R., Chen, W., Zheng, X. and Yu, T. (2013) Dietary Supplementation with Purified Mulberry (Morus australis Poir) Anthocyanins Suppresses Body Weight Gain in High-Fat Diet Fed C57BL/6 Mice. Food Chemistry, 141, 482-487. http://dx.doi.org/10.1016/j.foodchem.2013.03.046

[93] Lin, Y.L., Chang, Y.Y., Yang, D.J., Tzang, B.S. and Chen, Y.C. (2013) Beneficial Effects of Noni (Morinda citrifolia L.) Juice on Livers of High-Fat Dietary Hamsters. Food Chemistry, 140, 31-38. http://dx.doi.org/10.1016/j.foodchem.2013.02.035

[94] Zemel, M.B., Shi, H., Greer, B., Dirienzo, D. and Zemel, P.C. (2000) Regulation of Adiposity by Dietary Calcium. The FASEB Journal, 14, 1132-1138.

[95] Astrup, A., Dyerberg, J., Elwood, P., Hermansen, K., Hu, F.B., Jakobsen, M.U., Willett, W.C., et al. (2011) The Role of Reducing Intakes of Saturated Fat in the Prevention of Cardiovascular Disease: Where Does the Evidence Stand in 2010? The American Journal of Clinical Nutrition, 93, 684-688. http://dx.doi.org/10.3945/ajcn.110.004622

[96] Zemel, M.B., Thompson, W., Milstead, A., Morris, K. and Campbell, P. (2004) Calcium and Dairy Acceleration of Weight and Fat Loss during Energy Restriction in Obese Adults. Obesity Research, 12, 582-590. http://dx.doi.org/10.1038/oby.2004.67 
Scientific Research Publishing (SCIRP) is one of the largest Open Access journal publishers. It is currently publishing more than 200 open access, online, peer-reviewed journals covering a wide range of academic disciplines. SCIRP serves the worldwide academic communities and contributes to the progress and application of science with its publication.

Other selected journals from SCIRP are listed as below. Submit your manuscript to us via either submit@scirp.org or Online Submission Portal.
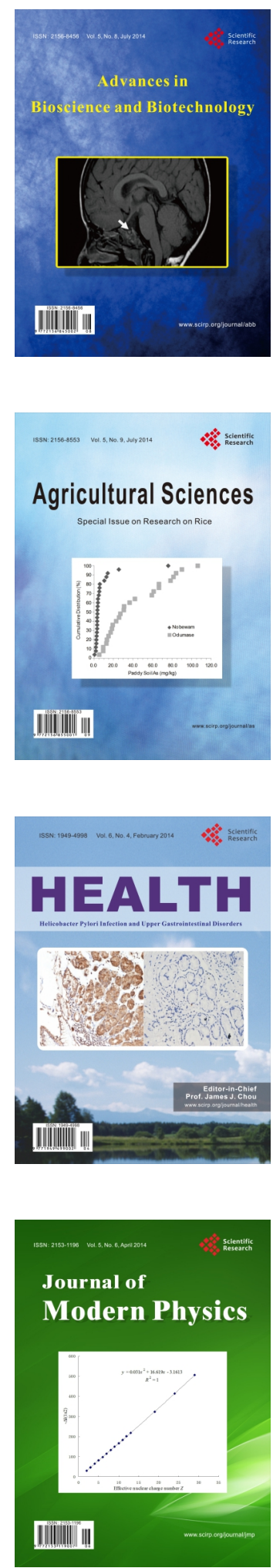
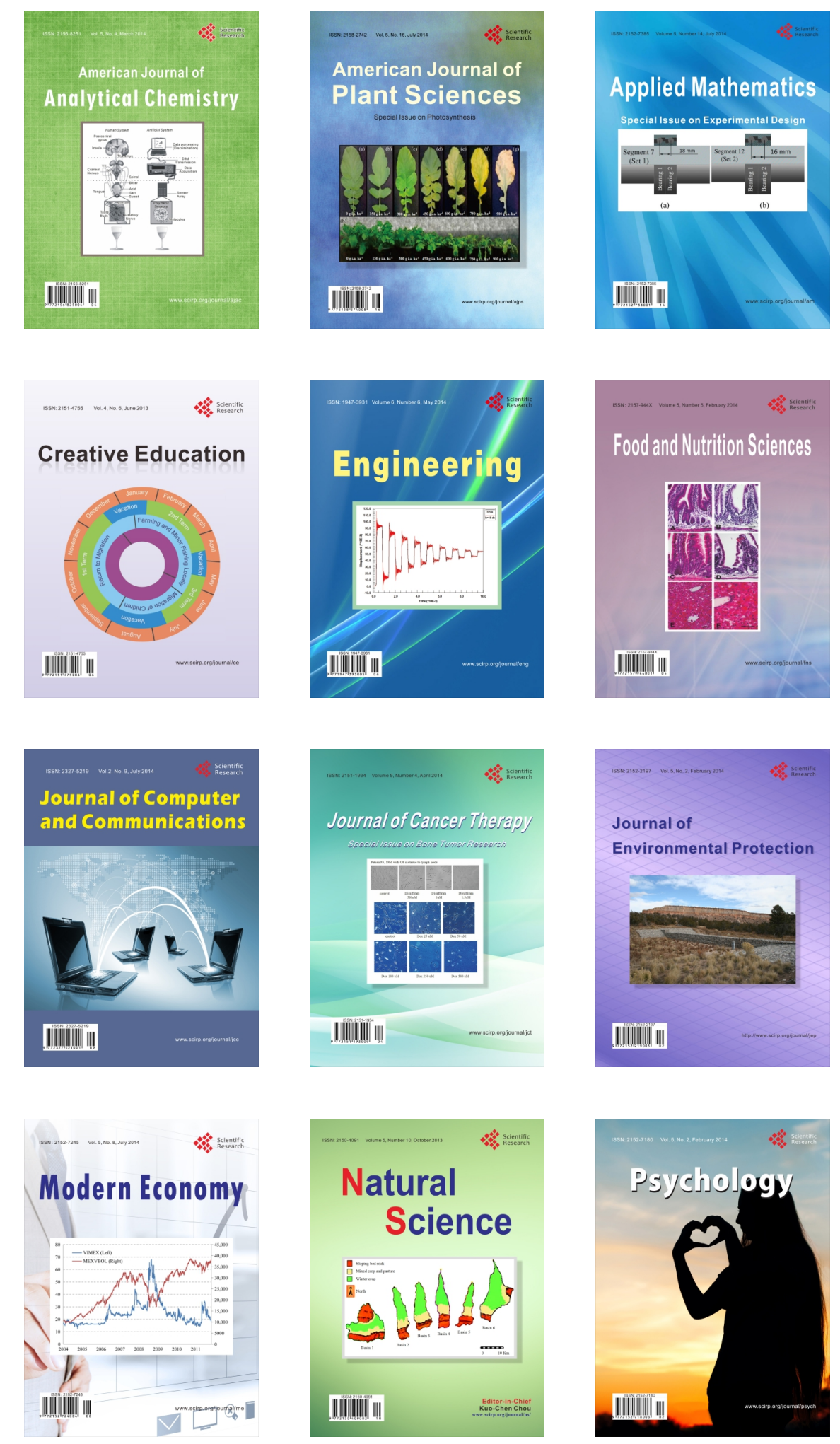